\title{
Patch test results in children and adolescents suffering from allergic contact dermatitis - comparison of patients with and without atopic dermatitis
}

\author{
Ocena wyników testów naskórkowych u dzieci i młodzieży z alergicznym \\ wypryskiem kontaktowym - porównanie grup pacjentów $\mathrm{z}$ atopowym zapaleniem \\ skóry i bez atopowego zapalenia skóry
}

Joanna Bacharewicz-Szczerbicka, Teresa Reduta, Anna Pawłoś, Iwona Flisiak

Department of Dermatology and Venereology, Medical University of Bialystok, Poland

Klinika Dermatologii i Wenerologii Uniwersytetu Medycznego w Białymstoku, Polska

Dermatol Rev/Przegl Dermatol 2017, 104, 77-91

DOI: https://doi.org/l0.51|4/dr.2017.6738|

CORRESPONDING AUTHOR/ ADRES DO KORESPONDENCJI: lek. med. Joanna Bacharewicz-Szczerbicka Klinika Dermatologii i Wenerologii Uniwersytet Medyczny w Białymstoku ul. Żurawia 14 15-540 Białystok, Poland tel.: +48 857409572 e-mail: asiabachar@wp.pl

\begin{abstract}
Introduction. Allergic contact dermatitis is a more and more frequently diagnosed skin disease in children and adolescents. It may coexist with atopic dermatitis. The frequency of allergy to certain contact haptens is determined by numerous factors.

Objective. To assess the frequency of allergy to selected contact allergens among children and adolescents with symptoms of contact eczema.

Material and methods. Two hundred seventy-three consecutive patients aged 4-18 years treated because of allergic contact eczema were included in this study. The demographic data and patch test results were assessed in the total group and separately in two age groups of patients without and with atopic dermatitis.

Results. The total group examined included 71 (44 female and 27 male) children and 202 (145 female and 57 male) adolescents. Atopic dermatitis was diagnosed in 64 patients. The patch test results were positive in $36.3 \%$ of examined subjects: $26.5 \%$ of children and $39.6 \%$ of adolescents, with a similar frequency in patients with and without atopic dermatitis. The most common contact sensitizers were nickel sulfate $(20.1 \%)$, cobalt chloride $(12.8 \%)$, p-phenylenediamine $(3.3 \%)$, potassium dichromate and fragrances (2.9\% each), balsam of Peru and neomycin sulfate $(1.5 \%$ each). Cobalt, chromate, fragrances and balsam of Peru more frequently sensitized patients with atopic dermatitis. Among the younger boys with atopic dermatitis there were no cases of contact allergy to nickel and cobalt, while in the atopic adolescent males the results with each of these allergens were positive in $20 \%$ of those examined.

Conclusions. Contact allergy is detected similarly frequent in children and adolescents with and without atopic dermatitis. The very high prevalence of allergy to nickel and cobalt is a significant problem among teenage girls and boys with atopic dermatitis.
\end{abstract}

\section{STRESZCZENIE}

Wprowadzenie. Alergiczny wyprysk kontaktowy jest dermatozą występującą obecnie coraz częściej u dzieci i młodzieży. Choroba może 
współistnieć z atopowym zapaleniem skóry. Częstość uczulenia na poszczególne alergeny kontaktowe zależy od wielu czynników.

Cel pracy. Ocena częstości uczulenia na wybrane alergeny u dzieci i młodzieży z alergicznym wypryskiem kontaktowym.

Materiał i metodyka. Badania przeprowadzono u 273 pacjentów w wieku 4-18 lat z alergicznym wypryskiem kontaktowym. Dane demograficzne i częstość uczulenia na alergeny oceniono w całej grupie badanej oraz oddzielnie $\mathrm{w}$ dwóch grupach wiekowych $\mathrm{u}$ chorych $\mathrm{z}$ atopowym zapaleniem skóry i bez atopowego zapalenia skóry.

Wyniki. Spośród 273 badanych 71 pacjentów (44 dziewczynki i 27 chłopców) stanowiły dzieci w wieku 4-13 lat, natomiast 202 osoby (145 dziewcząt i 57 chłopców) - młodzież w wieku 14-18 lat. Atopowe zapalenie skóry rozpoznano u 64 pacjentów. Dodatnie wyniki prób płatkowych stwierdzono u 36,3\% badanych: 26,8\% dzieci i 39,6\% młodzieży. Nie wykazano istotnych różnic $\mathrm{u}$ chorych $\mathrm{z}$ atopowym zapaleniem skóry $\mathrm{i}$ bez atopowego zapalenia skóry. Alergenami najczęściej uczulającymi były: nikiel $(20,1 \%)$, kobalt $(12,8 \%)$, parafenylenodwuamina $(3,3 \%)$, chrom i substancje zapachowe (po 2,9\%) oraz balsam peruwiański i neomycyna (po $1,5 \%$ ). Kobalt, chrom, substancje zapachowe i balsam peruwiański częściej uczulały chorych z atopowym zapaleniem skóry. Wśród młodszych chłopców z tym schorzeniem nie było przypadków uczuleń na nikiel i kobalt, natomiast wśród starszych z atopowym zapaleniem skóry dodatnie wyniki z każdym z tych alergenów stwierdzono u 20\% badanych.

Wnioski. Alergia kontaktowa wykrywana jest podobnie często u dzieci i młodzieży z atopowym zapaleniem skóry i bez atopowego zapalenia skóry. Istotny problem stanowi bardzo wysoki odsetek osób uczulonych na nikiel i kobalt wśród dziewcząt i nastoletnich chłopców z atopowym zapaleniem skóry.

Key words: children, adolescents, contact dermatitis, patch tests, contact allergens, atopic dermatitis.

Słowa kluczowe: dzieci, młodzież, wyprysk kontaktowy, testy płatkowe, alergeny kontaktowe, atopowe zapalenie skóry.

\section{INTRODUCTION}

Allergic contact dermatitis (ACD) is a skin disease associated with type IV allergic reaction (delayed hypersensitivity) mediated by T lymphocytes. It develops after contact of the small molecule compound hapten with the skin of sensitized persons. The prevalence of contact allergy in the general pediatric population has been estimated at 13.3$24.5 \%$, but in ACD at 35-66\% [1, 2]. Allergic contact dermatitis may develop already in infancy [3], and in teenagers it is considered as the most frequent form of eczema [4]. Because of the similar clinical picture ACD can be misdiagnosed as atopic eczema. Allergic contact dermatitis may also coexist with atopic dermatitis (AD), resulting in ACD diagnosis being missed in atopic children [5]. For that reason patch testing is indicated in all patients with chronic eczema and signs of lichenification. In diagnosis

\section{WPROWADZENIE}

Alergiczny wyprysk kontaktowy (ang. allergic contact dermatitis - ACD) należy do dermatoz związanych z IV typem reakcji wg Coombsa (nadwrażliwość typu późnego), w której zaangażowane są limfocyty T. Powstaje on w wyniku kontaktu skóry uczulonej osoby z haptenem, który stanowi drobnocząsteczkowy związek chemiczny. Wśród badanych dzieci alergię kontaktową stwierdza się u 13,3-24,5\%, a ze zmianami w postaci ACD u 35-66\% [1, 2]. Alergiczny wyprysk kontaktowy może się pojawić już w okresie noworodkowym [3], a u nastolatków jest uznawany za najczęstszą formę wyprysku [4]. Obraz kliniczny ACD u dzieci może być mylony ze zmianami w przebiegu atopowego zapalenia skóry (AZS) ze względu na zbliżoną morfologię zmian. Ponadto ACD niekiedy współistnieje z AZS, co może prowadzić do nierozpoznania istniejącej alergii kontaktowej [5]. W związku 
of contact allergy a positive patch test result with a given allergen and demonstration of its clinical relevance are important [5-8]. The most frequent contact allergens in children have been considered to be nickel, propolis, thimerosal, cobalt, chromate, fragrances, neomycin, and $p$-phenylenediamine (PPD) $[5,9,10]$. The literature data have indicated however significant differences in participation of individual allergens as a cause of ACD between different countries.

\section{OBJECTIVE}

The aim was to determine the frequency of contact allergy to selected allergens among children and adolescents with ACD in regard to demographic and clinical data and presence of AD.

\section{MATERIAL AND METHODS}

The study included 273 patients (age: 4 to 18 years) treated at the Department of Dermatology and Venereology and at the Dermatology Outpatient Clinic in the years 2006-2015 because of suspicion of ACD. Patients were divided into two age groups: children aged 4-13 years and adolescents aged 14-18 years. Demographic data and frequency of sensitization to specific allergens were assessed in the whole group and separately in groups of patients without AD and with AD.

Patch tests were performed in all patients during remission, after cessation of treatment with systemic and topical corticosteroids on the tested area 3 weeks prior to patch testing. They were not exposed to sunlight for at least 2 weeks. In all groups of patients patch tests were performed with set of 30 allergens included in the Baseline Standard Series (Chemotechnique Diagnostics, Sweden), extended by detreomycin (2\%, vaseline prepared at our pharmacy). Five children (aged 8-13 years) and 43 adolescents were tested with additional allergens of cosmetics, medicines and resin series, depending on the indication. Allergens (at the amount of $20 \mathrm{mg}$ of petrolatum preparations and $15 \mu$ l of solutions) were applied on the intact skin of the upper back using square $(8 \times 8 \mathrm{~mm})$ patches of filter paper and Omnipor tape (Hartmann, Germany) and left for 48 hours. The results were read on day 2, day 4 and day 7 and scored according to the International Contact Dermatitis Research Group recommendations [11].

The differences in frequency of positive patch test results between girls and boys, in two age groups of patients with and without AD, were assessed by a test of proportions. A $p$-value $<0.05$ was considered to be statistically significant. z tym u chorego z przewlekłymi zmianami wypryskowymi oraz cechami lichenizacji zaleca się wykonanie testów naskórkowych. O rozpoznaniu u dziecka ACD świadczy dodatni wynik testu płatkowego oraz potwierdzenie, że kontakt $\mathrm{z}$ daną substancją rzeczywiście wywołuje objawy chorobowe (wykazanie istotności klinicznej) [5-8]. Do najczęstszych alergenów kontaktowych u dzieci należą: nikiel, propolis, tiomersal, kobalt, chrom, substancje zapachowe, neomycyna, $p$ -fenylenodwuamina (PPD) $[5,9,10]$. Dane z piśmiennictwa wykazują jednak, że udział poszczególnych alergenów w ACD jest odmienny w różnych krajach.

\section{CEL PRACY}

Celem pracy jest ocena częstości uczulenia na wybrane alergeny u dzieci i młodzieży z ACD w odniesieniu do danych socjodemograficznych, klinicznych i obecności AZS.

\section{MATERIAŁ I METODYKA}

Badaniem objęto 273 pacjentów w wieku 4-18 lat leczonych w Klinice Dermatologii i Wenerologii i Poradni Dermatologicznej w latach 2006-2015 z powodu podejrzenia ACD. Chorzy zostali podzieleni na dwie grupy wiekowe: dzieci w wieku 4-13 lat oraz młodzież w wieku 14-18 lat. Dane demograficzne pacjentów oraz częstość uczulenia na poszczególne alergeny kontaktowe oceniano w całej grupie badanej oraz oddzielnie $u$ chorych bez AZS i z AZS.

Testy płatkowe wykonywano u wszystkich pacjentów w trakcie remisji klinicznej, przynajmniej 3 tygodnie po zakończeniu leczenia ogólnego glikokortykosteroidami i miejscowego stosowania tych leków na miejsca założenia testów. Skóra poddana próbom płatkowym nie była eksponowana na promieniowanie słoneczne przynajmniej przez 2 ostatnie tygodnie. U wszystkich wykonano testy płatkowe z zestawem 30 alergenów podstawowej serii (Chemotechnique Diagnostics, Szwecja) rozszerzonym o detreomycynę ( $2 \%, \mathrm{w}$ wazelinie przygotowanej przez aptekę szpitalną). U 5 dzieci w wieku 8-13 lat i u 43 nastolatków przeprowadzono próby z dodatkowymi alergenami z serii kosmetyków, leków i żywic w zależności od wskazań. Alergeny (w ilości 20 mg w wazelinie i $15 \mu 1$ roztworu) aplikowano na niezmienioną skórę pleców na kwadratowym $(8 \times 8 \mathrm{~mm})$ płatku bibuły przy użyciu taśmy Omnipor (Hartmann, Niemcy) i pozostawiano na 48 godzin. Wyniki prób odczytywano po 2, 4 i 7 dniach, a następnie oceniano wg zasad International Contact Dermatitis Research Group [11].

Różnice w zakresie częstości występowania dodatnich wyników prób pomiędzy dziewczynkami i chłopcami w dwóch grupach wiekowych oraz różnice pomiędzy chorymi z AZS i bez AZS oceniano 


\section{RESULTS}

The demographic and clinical data of the patients are presented in Table 1. Of the total 273 patients, 71 (44 female and 27 male) were children and 202 (145 female and 57 male) were adolescents. The mean age of the younger girls was 10.4 years and of the female adolescents was 16.6 years. The mean age of both age groups of boys was 10.8 and 16.3 respectively. Atopic dermatitis was diagnosed in 64 patients: 18 (9 female and 9 male) children and 46 (30 female and 16 male) adolescents on the basis of Hanifin's and Rajka's criteria [12]. In total $215(78.8 \%)$ of those examined were city inhabitants, while the remaining 58 (37 female and 21 male) patients lived in rural regions.

The hands were affected in 120 (44\%) patients. Disseminated eczema was diagnosed in 81 (29.7\%) examined patients. The face and ears were affected in $15(5.5 \%)$ and $5(1.8 \%)$ respectively and the other body areas in $38(13 \%)$ of examined patients.

Positive patch test reactions were found in $99(36 \%)$ patients: 19 (26.8\%) children and 80 (39.6\%) adolescents. The frequencies of positive results with individual allergens are shown in Table 2 . The most commonly detected allergens in all patients were: nickel sulfate giving positive results in 55 (20.1\%) patients, cobalt chloride - $35(12.8 \%)$ positive reactions, PPD - $9(3.3 \%)$, potassium dichromate and fragrances 8 (2.9\% each) positive results. The less frequent contact allergies were to: balsam of Peru and neomycin $(1.5 \%$ each) and IPPD $-1.1 \%$ of positive results. Less than $1 \%$ of sensitized patients were obtained with quaternium, propolis, turpentine, wool alcohols, tixocortol-21-pivalate, mercaptobenzothiazole (MBT) and detreomycin. Solitary cases of allergy were observed with colophony, mercury chloride, palladium chloride, primin, lactone mix, thiuram, methylchloroisothiazolinone/methylisothiazolinone (MCI/MI), paraben mix, cobalt naphthenate and benzocaine.

Among children an allergy to nickel was observed exclusively in girls (20.5\% of those examined), while in adolescents positive results with nickel were observed in $29 \%$ of girls and $7 \%$ of boys.

Contact allergy to cobalt chloride was observed in $9.1 \%$ of the younger girls and in $18.6 \%$ of the girls aged 14-18 years, in two age groups of boys in 3.7\% and $5.3 \%$ respectively. The percentage of positive results with p-phenylenediamine was $2.3 \%$ in female children, $3.4 \%$ of female adolescents and $5.3 \%$ of male boys aged 14-18 years. There were no cases of PPD allergy among younger boys. Hypersensitivity to potassium dichromate was found in $4.5 \%$ of girls and $7.4 \%$ of boys, while among adolescents it was detected only in girls $(2.6 \%)$. przy użyciu testu dla dwóch wskaźników struktury. Wartość $p<0,05$ przyjęto jako istotną statystycznie.

\section{WYNIKI}

Dane demograficzne i kliniczne badanych pacjentów przedstawiono w tabeli 1 . Wśród 273 pacjentów było 71 (44 dziewczynki i 27 chłopców) dzieci i 202 osoby (145 dziewcząt i 57 chłopców) w grupie młodzieży. Średnia wieku dziewczynek wyniosła 10,4 roku, a średnia wieku dziewcząt 16,5 roku. Wśród chłopców średnie wieku wyniosły odpowiednio 10,8 i 16,3 roku. Atopowe zapalenie skóry rozpoznano u 64 pacjentów: 18 dzieci (9 dziewczynek i 9 chłopców) oraz 46 nastolatków (30 dziewcząt i 16 chłopców) na podstawie kryteriów Hanifina i Rajki [12]. Ogółem tereny miejskie zamieszkiwało 215 (78,8\%) osób, a tereny wiejskie pozostałych 58 badanych ( 37 dziewcząt i 21 chłopców).

Zmiany na rękach stwierdzono u 120 (44\%) osób. Wyprysk rozsiany rozpoznano u $81(29,7 \%)$ badanych. Twarz i uszy były zajęte odpowiednio u 15 (5,5\%) i $5(1,8 \%)$, natomiast inne okolice u 38 (13\%) badanych.

Dodatnie wyniki prób płatkowych stwierdzono u 99 (36\%) badanych: 19 (26,8\%) dzieci i 80 (39,6\%) w grupie młodzieży. Częstość uczulenia na wybrane alergeny kontaktowe przedstawiono w tabeli 2 . W całej badanej grupie najczęściej dodatnie próby uzyskano z siarczanem niklu - 55 (20,1\%) osób, chlorkiem kobaltu - 35 (12,8\%) osób, PPD - 9 (3,3\%) osób oraz z dwuchromianem potasu i substancjami zapachowymi - po 8 (2,9\%) badanych. Rzadziej stwierdzono uczulenie na balsam peruwiański i neomycynę (po $1,5 \%$ badanych) oraz Nonox ZA (1,1\% badanych). Poniżej $1 \%$ pacjentów było uczulonych na quaternium, propolis, terpentynę, lanolinę, piwalan tiksokortolu, merkaptobenzotiazol (MBT) oraz detreomycynę. Pojedyncze przypadki uczuleń dotyczyły kalafonii, chlorku rtęci, chlorku palladu, priminy, lactone mix, tiuramu, metylochloroizotiazolinonu/metyloizotiazolinonu (MCI/MI), aseptyny, naftenianu kobaltu i benzokainy.

U dzieci uczulenie na siarczan niklawy stwierdzono wyłącznie u dziewczynek (20,5\% badanych), u młodzieży alergia na nikiel dotyczyła 29\% dziewcząt i 7\% chłopców.

Alergia kontaktowa na chlorek kobaltu występowała u 9,1\% dziewczynek i 18,6\% dziewcząt w wieku 14-18 lat i odpowiednio u 3,7\% i 5,3\% chłopców. Odsetek uczuleń na $p$-fenylenodwuaminę wynosił u dziewczynek 2,3\%, u dziewcząt 3,4\%, u badanych płci męskiej alergię na PPD stwierdzono jedynie u chłopców w wieku 14-18 lat (5,3\%). Nie obserwowano przypadków uczuleń na PPD w grupie młodszych chłopców. Nadwrażliwość na dwuchromian potasu stwierdzono u 4,5\% dziewczynek oraz 7,4\% chłopców, natomiast 


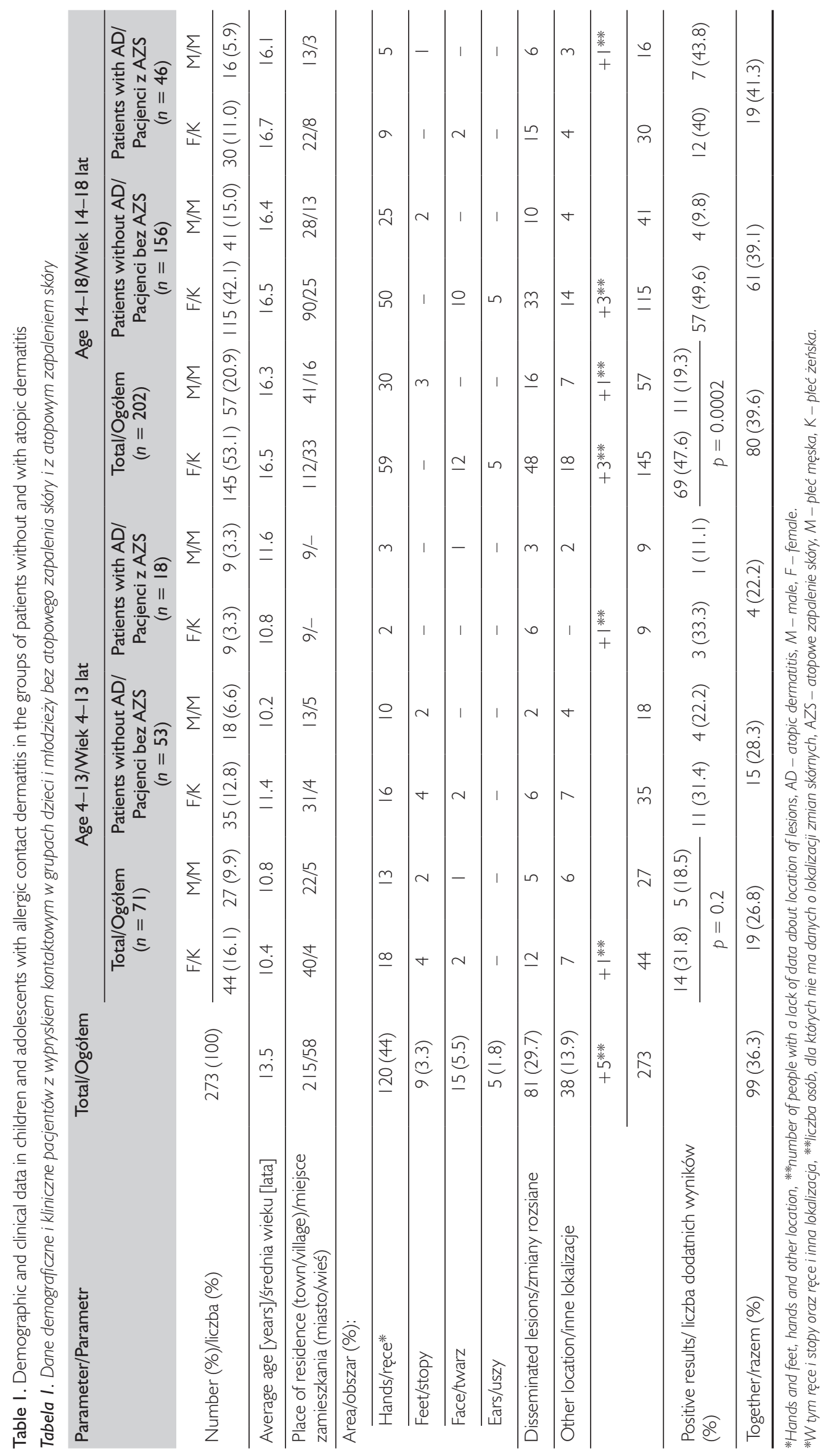


Table 2. Frequency of positive patch test results in two age groups of patients

Tabela 2. Częstość mystępowania dodatnich wyników prób płatkowych w dwóch grupach wiekowych

\begin{tabular}{|c|c|c|c|c|c|c|c|}
\hline \multirow[t]{3}{*}{ Parameter/Parametr } & \multicolumn{7}{|c|}{ Number of positive results (\%)/Liczba pacjentów z wynikiem dodatnim (\%) } \\
\hline & \multicolumn{3}{|c|}{$\begin{array}{c}\text { Age 4-I8/Wiek 4-18 lat } \\
(n=273)\end{array}$} & \multicolumn{2}{|c|}{$\begin{array}{c}\text { Age 4-I3/Wiek 4-I3 lat } \\
(n=7 I)\end{array}$} & \multicolumn{2}{|c|}{$\begin{array}{c}\text { Age I4-I8/Wiek I4-18 lat } \\
\quad(n=202)\end{array}$} \\
\hline & $\begin{array}{c}\text { Total/ } \\
\text { Ogółem } \\
(n=273)\end{array}$ & $\begin{array}{c}\mathrm{F} / \mathrm{K} \\
(n=189)\end{array}$ & $\begin{array}{c}M / M \\
(n=84)\end{array}$ & $\begin{array}{c}\mathrm{F} / \mathrm{K} \\
(n=44)\end{array}$ & $\begin{array}{c}M / M \\
(n=27)\end{array}$ & $\begin{array}{c}F / K \\
(n=145)\end{array}$ & $\begin{array}{c}M / M \\
(n=57)\end{array}$ \\
\hline $\begin{array}{l}\text { Nickel sulfate/ } \\
\text { siarczan niklawy }\end{array}$ & $55(20.1)$ & $51(27.0)$ & $4(4.8)^{\#, * * * *}$ & $9(20.5)$ & - & $42(29.0)$ & $4(7.0)$ \\
\hline $\begin{array}{l}\text { Cobalt chloride/ } \\
\text { chlorek kobaltu }\end{array}$ & $35(12.8)$ & $31(16.4)$ & $4(4.8)^{\#, *}$ & $4(9.1)$ & I (3.7) & $27(18.6)$ & $3(5.3)$ \\
\hline $\begin{array}{l}\text { Paraphenylenediamine/ } \\
\text { parafenylenodwuamina }\end{array}$ & $9(3.3)$ & $6(3.2)$ & $3(3.6)$ & I (2.3) & - & $5(3.4)$ & $3(5.3)$ \\
\hline $\begin{array}{l}\text { Potassium dichromate/ } \\
\text { dwuchromian potasu }\end{array}$ & $8(2.9)$ & $6(3.2)$ & $2(2.4)$ & $2(4.5)$ & $2(7.4)$ & $4(2.6)$ & $-\#, *$ \\
\hline $\begin{array}{l}\text { Fragrance mix/ } \\
\text { substancje zapachowe }\end{array}$ & $8(2.9)$ & $7(3.7)$ & । ( 1.2$)$ & $2(4.5)$ & - & $5(3.4)$ & । (I.8) \\
\hline $\begin{array}{l}\text { Balsam of Peru/ } \\
\text { balsam peruwiański }\end{array}$ & $4(1.5)$ & $3(1.6)$ & । (I.2) & I (2.3) & - & $2(1.4)$ & । (I.8) \\
\hline $\begin{array}{l}\text { Neomycin sulfate/ } \\
\text { neomycyna }\end{array}$ & $4(1.5)$ & $3(1.6)$ & । (I.2) & I (2.3) & I (3.7) & $2(1.34)$ & - \\
\hline $\begin{array}{l}\mathrm{N} \text {-Isopropyl-N-phenyl-4- } \\
\text { phenylenediamine (IPPD)/ } \\
\text { Nonox ZA }\end{array}$ & $3(1.1)$ & $2(1.1)$ & I ( 1.2$)$ & $2(4.5)$ & I (3.7) & $-{ }^{\#, *}$ & - \\
\hline Quaternium- I5/quaternium & $2(0.7)$ & $2(1.1)$ & - & - & - & $2(1.4)$ & - \\
\hline Propolis/propolis & $2(0.7)$ & $2(1.1)$ & - & - & - & $2(1.4)$ & - \\
\hline Turpentine/terpentyna & $2(0.7)$ & $2(1.1)$ & - & $2(4.5)$ & - & $-\#, *$ & - \\
\hline Lanolin alcohol/lanolina & $2(0.7)$ & I (0.5) & । ( 1.2$)$ & I (2.3) & - & - & I ( 1.8$)$ \\
\hline $\begin{array}{l}\text { Tixocortol-2I-pivalate/ } \\
\text { piwalan tiksokortolu }\end{array}$ & $2(0.7)$ & I (0.5) & । (I.2) & - & - & I (0.7) & I ( 1.8$)$ \\
\hline $\begin{array}{l}\text { Mercaptobenzothiazole/ } \\
\text { merkaptobenzotiazol }\end{array}$ & $2(0.7)$ & I (0.5) & I ( 1.2$)$ & I (2.3) & I (3.7) & - & - \\
\hline Detreomycin/detreomycyna & $2(0.7)$ & I (0.5) & । ( $(1.2)$ & I (2.3) & I (3.7) & I $(0.7)$ & - \\
\hline Colophonium/kalafonia & I (0.4) & I (0.5) & - & - & - & I (0.7) & - \\
\hline $\begin{array}{l}\text { Mercury chloride/ } \\
\text { chlorek rtęci }\end{array}$ & I (0.4) & I (0.5) & - & - & - & I (0.7) & - \\
\hline $\begin{array}{l}\text { Palladium chloride/ } \\
\text { chlorek palladu }\end{array}$ & I $(0.4)$ & I (0.5) & - & - & - & I (0.7) & - \\
\hline Primin/primina & I (0.4) & I (0.5) & - & - & - & I (0.7) & - \\
\hline Lactone mix/lactone mix & I (0.4) & I (0.5) & - & - & - & I (0.7) & - \\
\hline Thiuram/tiuram & I (0.4) & I (0.5) & - & I (2.3) & - & - & - \\
\hline $\begin{array}{l}\text { Methylchloroisothiazolinone/ } \\
\text { methylisothiazolinone/ } \\
\text { metylochloroizotiazolinon/ } \\
\text { metyloizotiazolinon }\end{array}$ & I (0.4) & I (0.5) & - & - & - & I (0.7) & - \\
\hline Parabens/aseptyna & I (0.4) & I (0.5) & - & I (2.3) & - & - & - \\
\hline $\begin{array}{l}\text { Cobalt naphthenate/ } \\
\text { naftenian kobaltu }\end{array}$ & I (0.4) & I (0.5) & - & - & - & I (0.7) & - \\
\hline Benzocaine/anestezyna & I (0.4) & - & । (I.2) & - & I (3.7) & - & - \\
\hline
\end{tabular}


In children allergy to fragrances was diagnosed only in the girls (4.5\% positive results), in adolescents both in females (3.4\%) and males $(1.8 \%)$. Balsam of Peru was the cause of allergy in $2.3 \%$ of younger girls and in $1.4 \%$ of girls and $1.8 \%$ of boys aged 14-18 years. The percentage of positive patch test results with neomycin was in female and male children $2.3 \%$ and $3.7 \%$ respectively, while in adolescents allergy to this antibiotic was observed only in females $(1.3 \%)$. The positive patch test results in the groups of patients with and without AD are shown in Table 3. Allergy to nickel was found in $23.1 \%$ of patients without $\mathrm{AD}$ and in $9.8 \%$ of $\mathrm{AD}$ patients, allergy to cobalt in $11.3 \%$ and $18 \%$ respectively. None of the younger boys were allergic to nickel and cobalt, but $20 \%$ of boys aged $14-18$ had positive tests with each of these metals. Paraphenylenediamine gave $3.8 \%$ of positive results in the patients without and in $1.6 \%$ with AD. Allergy to chromate and balsam of Peru was detected in $8.2 \%$ of atopics and in $1.4 \%$ without AD. Allergy to turpentine, wool alcohol, thiuram, MCI/MI and parabens was observed only in children and adolescents with AD. Among the AD patients there was no allergy to neomycin, quaternium, MBT, colophony, mercury chloride, palladium chloride, primin, lactone mix, or benzocaine.

The distribution of skin lesions depending on the most frequent allergens is shown in Table 4 . In the non-atopic girls allergic to nickel and cobalt hand dermatitis affected $29.2 \%$ and $34.8 \%$ of patients respectively. In AD girls with allergy to nickel skin lesions were only disseminated, while in those allergic to cobalt scattered eczema afflicted $62.5 \%$ and hands $37.5 \%$ of patients. In non-atopic boys sensitized to the two most frequent allergens hand involvement was observed in 4 of 6 cases, and in boys with AD in 6 of 8 cases.

\section{DISCUSSION}

The demographic data analysis showed the predominance of girls in both age groups, which probably reflects the higher exposure to cosmetics and jewelry among girls. The exception was children with $\mathrm{AD}$, with equal representation of girls and boys, indicating the importance of skin barrier impairment in development of ACD.

The majority (79\%) of the total group and all of the AD patients were city inhabitants, indicating the harmful influence of the industrial environment; it may also, at least partially, result from the limited access of the patients from rural regions to a specialist.

The hands were the most frequently involved body areas in both age groups both in patients with u młodzieży alergia ta dotyczyła wyłącznie dziewcząt $(2,6 \%)$.

U dzieci alergię na substancje zapachowe stwierdzono tylko u dziewczynek (4,5\% dodatnich wyników), u młodzieży wykazano ją u obu płci (3,4\% dziewcząt i 1,8\% chłopców). Odsetek uczuleń na balsam peruwiański wynosił 2,3\% u dziewczynek oraz 1,4\% u dziewcząt i 1,8\% u nastoletnich chłopców. Testy naskórkowe wykazały nadwrażliwość na neomycynę u 2,3\% dziewczynek i 3,7\% chłopców, wśród młodzieży alergia na ten antybiotyk występowała wyłącznie u dziewcząt (1,3\%). Dodatnie wyniki prób płatkowych u dzieci i młodzieży bez AZS i z AZS przedstawiono $\mathrm{w}$ tabeli 3 . Uczulenie na nikiel stwierdzono u 23,1\% chorych bez AZS i 9,8\% pacjentów z AZS, uczulenie na kobalt - odpowiednio u 11,3\% i 18\% badanych. U młodszych chłopców z AZS nie było przypadków uczuleń na nikiel i kobalt, natomiast wśród starszych chłopców z AZS dodatnie wyniki z każdym z tych alergenów stwierdzono u 20\%. Dodatnie próby z PPD stwierdzono u 3,8\% bez AZS oraz $1,6 \%$ z AZS. Chrom i substancje zapachowe uczulały $8,2 \%$ chorych z AZS i 1,4\% bez AZS, balsam peruwiański - 4,9\% pacjentów z AZS i 0,5\% bez AZS. Alergię na terpentynę, lanolinę, tiuram, MCI/MI i parabeny stwierdzono jedynie $u$ dzieci i młodzieży z AZS. U pacjentów z AZS nie stwierdzono uczuleń na neomycynę, quaternium, MBT, kalafonię, chlorek rtęci, chlorek palladu, priminę, lactone mix i benzokainę.

Lokalizację zmian skórnych w zależności od najczęściej uczulającego alergenu przedstawiono $\mathrm{w}$ tabeli 4. Wśród dziewcząt bez AZS uczulonych na siarczan niklawy i chlorek kobaltu stwierdzono zmiany na rękach u 29,2\% i 34,8\% badanych. U dziewcząt z AZS i alergią na nikiel zmiany miały charakter wyłącznie rozsiany, natomiast w przypadku uczulenia na kobalt zmiany rozsiane stwierdzono u $62,5 \%$ badanych, w pozostałych przypadkach zmiany dotyczyły rąk (37,5\%). U chłopców bez AZS uczulonych na te dwa najczęstsze alergeny zmiany obejmowały skórę rąk w 4 na 6 przypadków uczuleń, a u chłopców z AZS w 6 na 8 przypadków.

\section{OMÓWIENIE}

Analiza danych demograficznych wykazała przewagę dziewcząt w obu grupach wiekowych, co prawdopodobnie jest odzwierciedleniem częstszej ekspozycji dziewcząt na kosmetyki i biżuterię. Jedynie u dzieci z AZS liczba dziewczynek i chłopców była jednakowa, co wskazuje na znaczenie upośledzenia funkcji bariery naskórkowej w rozwoju ACD.

Większość grupy badanej (79\%) i wszyscy pacjenci z AZS zamieszkiwali tereny miejskie. Fakt ten może wskazywać na niekorzystny wpływ środowiska miejskiego na rozwój AZS, ale może również wynikać 


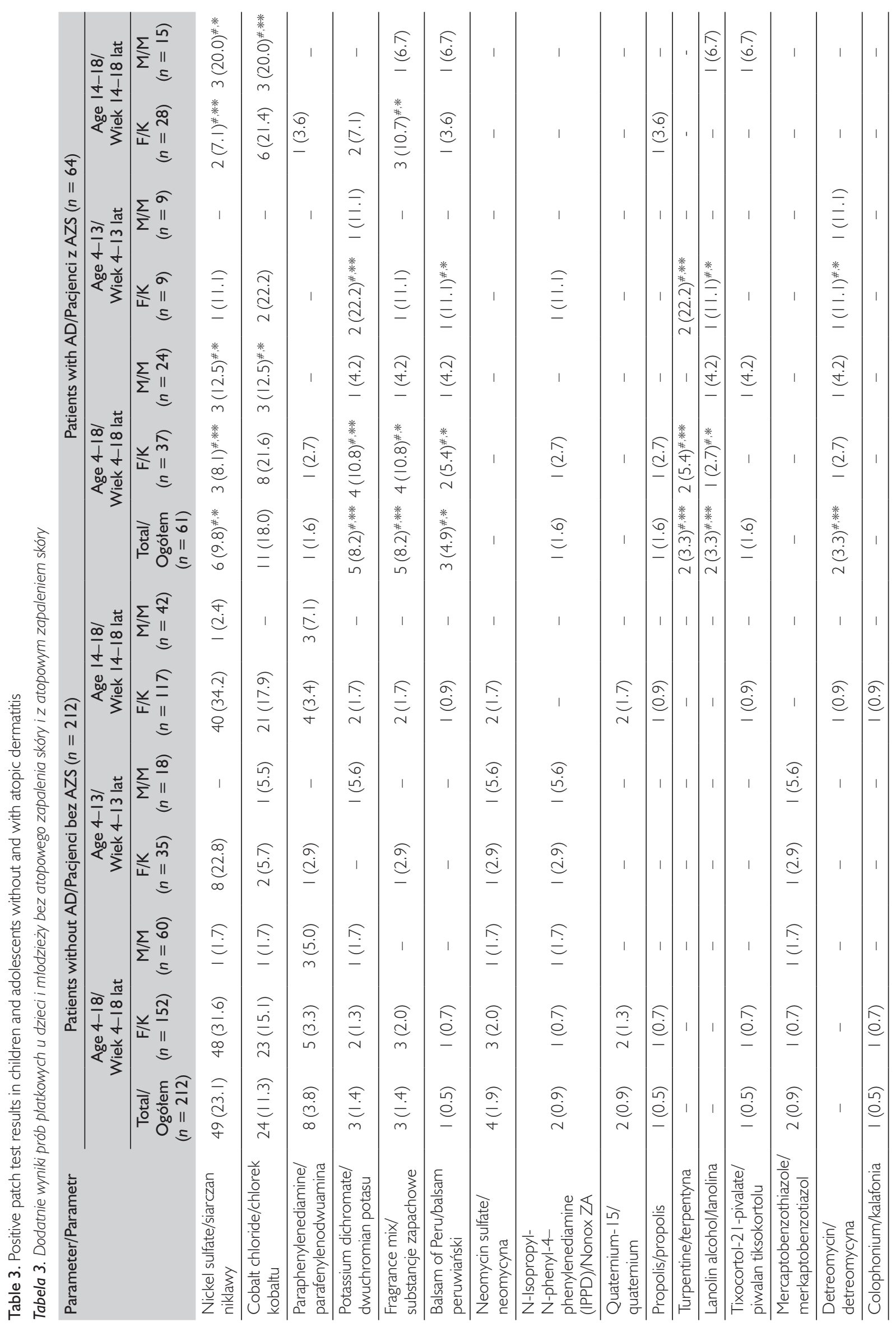




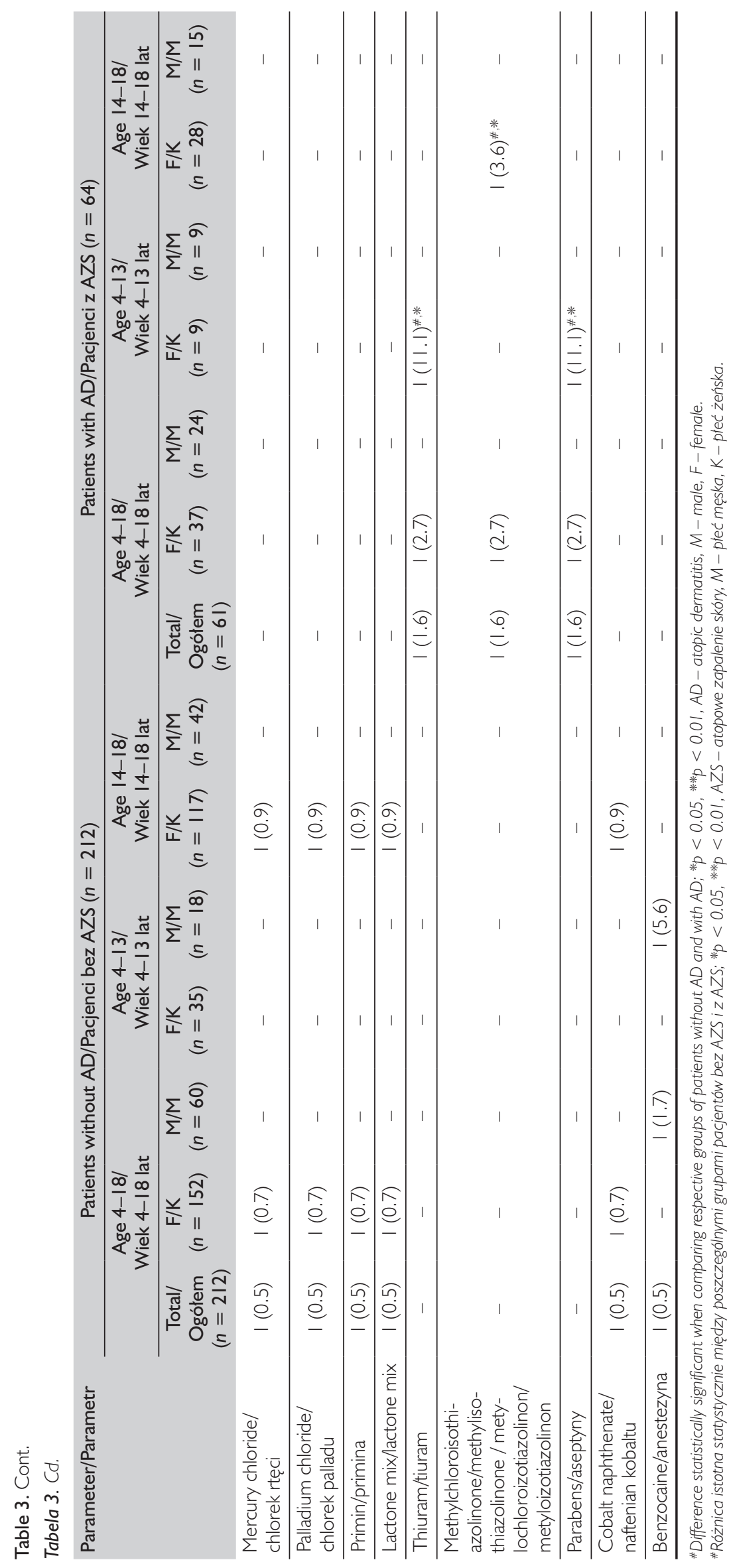




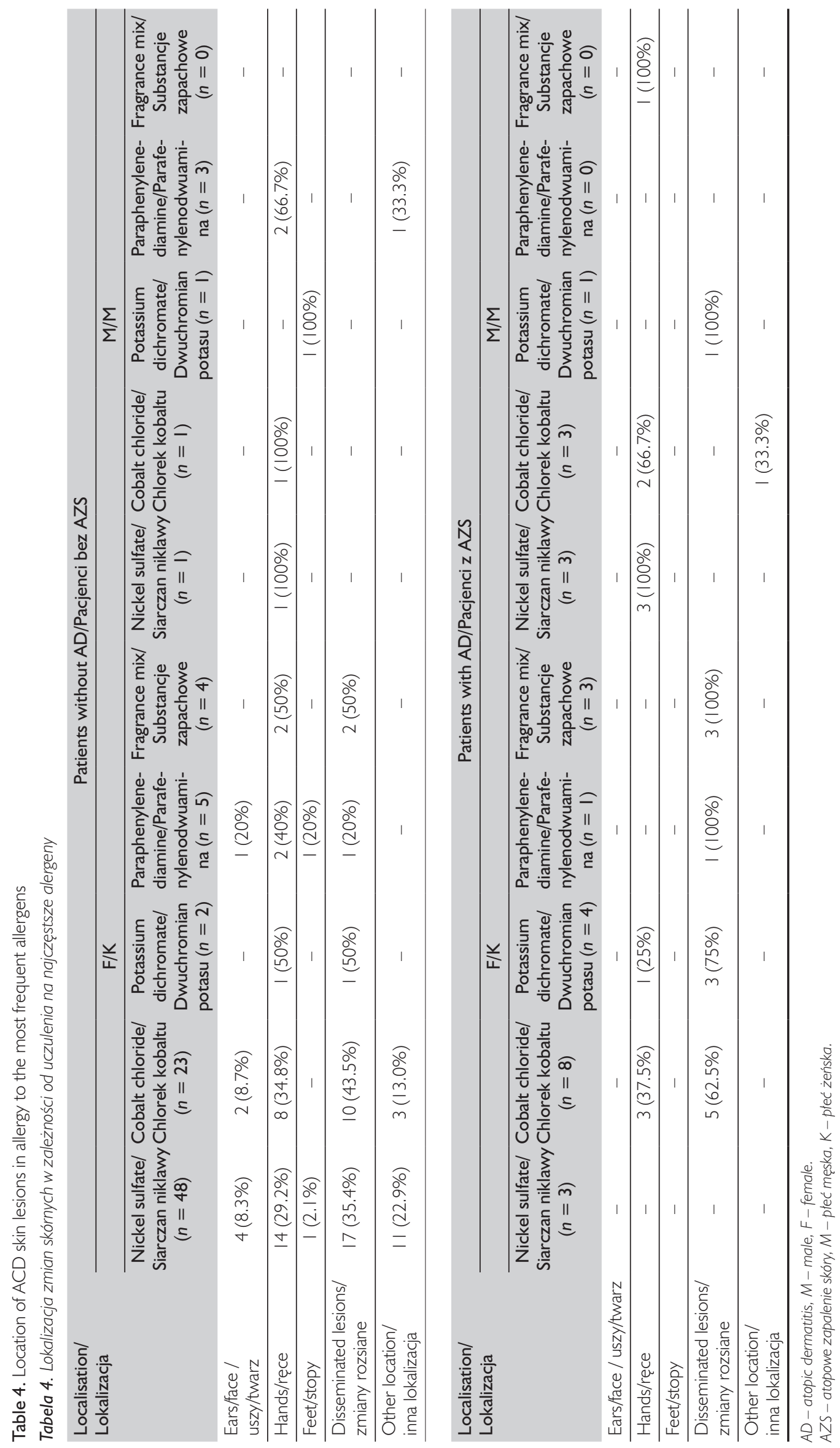


and without AD. Disseminated eczema was the second most frequent clinical pattern of skin lesions, especially in AD patients, but the face was affected most frequently in female adolescents, which may be associated with extensive cosmetics and jewelry use in that group.

According to the literature data, positive patch test results in children with ACD have been estimated in $26.6-95.6 \%$ of those examined [13]. In this study the percentage of positive results in children $(26.8 \%)$ was lower than in adolescents (39.6\%), which is not consistent with other investigations showing a higher allergy rate in children, especially in those under 3 years of age [14,15]. The sensitization rate was significantly higher in females of both age groups than in males.

In $\mathrm{AD}$ patients the frequency of positive results was $22.2 \%$ in children and $41.3 \%$ in adolescents, which is concordant with literature data estimating such results in $\mathrm{AD}$ children ranging from $14 \%$ to $64 \%[16,17]$. No differences between AD patients and nonatopic ones were found in the sensitization rate.

The EU Nickel Directive regulating permitted nickel concentration in objects intended for close skin contact came into force in 2001 to prevent nickel allergy, but in many countries this allergen is still the most frequent cause of ACD in children and adolescents [18-21]. The results of our study support this observation; in our patients the frequency of nickel allergy was $20.1 \%$, with prevalence of girls $(27 \%)$. It should be emphasized that nickel allergy affected mainly female teenagers (29\%) and only $7 \%$ of male adolescents. There was no case of nickel allergy among younger boys. This difference can be explained by the early exposure to imitation jewelry in girls. The other sources of this allergen are jeans studs, buttons, dental alloys, mobile phones and tablets. Comparing the results of the adult population from the Bialystok center in 2007-2011 showed a similar percentage of allergies in examined children - 24\% [22].

The second most common allergen in the researched group was cobalt chloride, giving $12.8 \%$ positive results. According to literature data the frequency of positive tests with this allergen in children ranges between $4 \%$ and $12.3 \%$ [10, 15, 23]. In our studies, as in the case of nickel, cobalt contact allergy was observed much more frequently among girls (16.4\%), particularly at the age of 14-18 (18.62\%). These values are similar to those observed among adults with contact eczema examined in Bialystok, but they are higher than in other European countries $[22,24]$.

Another common allergen among the studied patients was PPD, giving $3.3 \%$ positive results. Par- z ograniczonego dostępu do placówek dermatologicznych na terenach wiejskich.

Zmiany na rękach występowały u największej liczby badanych, z podobną częstością u osób z AZS i bez AZS. Nieco rzadziej zmiany miały charakter rozsiany, szczególnie u pacjentów z AZS, natomiast twarz była zajęta najczęściej u dziewcząt, co najprawdopodobniej wynika z częstego używania kosmetyków, farbowania włosów i noszenia biżuterii.

Według danych z piśmiennictwa dodatnie wyniki testów naskórkowych stwierdza się u 26,6-95,6\% dzieci z ACD [13]. W przedstawionych wynikach odsetek dodatnich prób $(26,8 \%)$ był u dzieci niższy niż u młodzieży $(39,6 \%)$. Niektóre badania wskazują natomiast na częstsze występowanie dodatnich prób naskórkowych u dzieci, zwłaszcza poniżej 3. roku życia, w porównaniu z młodzieżą [14, 15]. W obu grupach wiekowych odsetek dodatnich wyników był istotnie wyższy u dziewcząt niż u chłopców.

U badanych chorych na AZS odsetek dodatnich wyników wyniósł u dzieci 22,2\%, a u młodzieży $41,3 \%$, co jest zbieżne $\mathrm{z}$ danymi z piśmiennictwa, wg których występowanie alergii kontaktowej u dzieci z AZS ocenia się na 14-64\% [16, 17]. Nie stwierdzono istotnej różnicy w zakresie częstości występowania uczulenia pomiędzy pacjentami z AZS i bez AZS.

W celu ograniczenia występowania alergii na nikiel w 2001 r. wprowadzono w obrębie Unii Europejskiej regulację prawną, tzw. Europejską Dyrektywę Niklową, określającą dopuszczalną zawartość niklu w przedmiotach mających kontakt ze skórą. Pomimo tego w wielu krajach siarczan niklawy nadal jest najczęstszą przyczyną ACD u dzieci i młodzieży [18-21]. Wyniki naszych badań również potwierdzają te obserwacje; w badanej grupie częstość uczulenia na nikiel wyniosła 20,1\%, z przewagą płci żeńskiej (27\%). Warto zaznaczyć, że alergia ta dotyczyła 29\% nastoletnich dziewcząt i jedynie 7\% starszych chłopców. U młodszych chłopców nie stwierdzono przypadków uczuleń na ten metal. Różnice w zakresie częstości występowania alergii na nikiel u obu płci można wyjaśnić wczesną ekspozycją na sztuczną biżuterię u dziewczynek. Innymi źródłami tego alergenu są nity w dżinsach, guziki, aparaty ortodontyczne, telefony komórkowe i tablety. Porównując wyniki badań grupy osób dorosłych z ośrodka białostockiego z lat 2007-2011, wykazano podobny odsetek uczuleń jak u dzieci - 24\% badanych [22].

Drugim co do częstości występowania alergenem był w badanej grupie chlorek kobaltu - 12,8\% wyników dodatnich. Według danych z piśmiennictwa częstość występowania dodatnich prób z tym alergenem u dzieci wynosi 4-12,3\% [10, 15, 23]. W naszych badaniach, podobnie jak w przypadku niklu, alergię kontaktową na kobalt stwierdzono znacznie częściej u dziewcząt (16,4\%), zwłaszcza w wieku 14-18 lat $(18,62 \%)$. Wartości te są zbliżone do obserwowanych 
aphenylenediamine is a pigment called "artificial henna", which is component of hair dyes, fabrics and furs [25]. In recent years there has been an increase in frequency of sensitization to this allergen, which most likely is associated with fashionable among young people having 'holiday tattoos' and early hair coloring [26]. In the pediatric population, allergy to PPD is in the range of $1.6-4.0 \%$, as shown in the above results $[10,21,27]$. The frequency of sensitization to PPD was higher in adolescents than in children.

A similar proportion of allergies (2.93\% each), in the whole studied group, was observed with potassium dichromate and aroma substances. Earlier, chrome was more allergenic among male patients. Our results show that, among children, allergy to this compound equally frequently concerned girls and boys. This fact may be related to the presence of the allergen in leather objects. The percentage of positive results with potassium dichromate was lower than in other centers (5.1-7.3\%) and lower than in the adult population of Bialystok center (6.8-8.7\%) [5, $15,16,22]$.

Aromatic substances are used widely as fragrances in the cosmetic industry. Personal care products used in early childhood, as well as creams and perfumes used by young people, constitute a frequent source of contact allergy. In the whole studied group, the percentage of allergic to fragrances was $2.9 \%$, and it was three times lower than in adults $(8.3 \%)$, indicating a systematic increase in the number of patients allergic to this group of compounds with age [22]. Allergy to aromatic substances appeared three times more frequently among girls than among boys.

Another frequent allergen observed in examined patients was balsam of Peru. This material is obtained from the tree Myroxylon balsamum and has a characteristic pleasant smell, similar to vanilla and cinnamon. It also possesses fixative and antiseptic properties. For these reasons, it is a common ingredient of cosmetics, perfumes and food products. In the overall group, this allergy equally often concerned girls and boys.

Neomycin applied topically can cause changes of a contact dermatitis. Allergy to neomycin is in the range $4.3-7.1 \%[10,15,23]$. In the present study the frequency was $1.5 \%$, with a predominance of girls. The frequency of sensitization to this allergen was three times lower compared to the population of adults. This may result from the use of this antibiotic especially in adults treated for venous leg ulcers. It should also be remembered that neomycin as one of the components of the finished drug is widely used, especially in the pediatric population, for various diseases of allergic, bacterial and fungal conditions. u dorosłych z wypryskiem kontaktowym badanym w ośrodku białostockim, lecz są wyższe niż w innych krajach europejskich [22, 24].

Kolejnym częstym alergenem okazała się PPD, która dała 3,3\% wyników dodatnich. Parafenylenodwuamina jest barwnikiem nazywanym "sztuczną henną", który wchodzi w skład farb do włosów, tkanin oraz futer [25]. Ostatnio obserwuje się wzrost uczuleń na ten alergen, co wiąże się prawdopodobnie z modnymi wśród młodzieży tzw. tatuażami wakacyjnymi oraz wczesnym farbowaniem włosów [26]. W populacji dziecięcej uczulenie na PPD wynosi 1,6-4,0\%, podobnie jak w przedstawionych powyżej wynikach [10, 21, 27]. Częstość uczuleń na PPD była wyższa u młodzieży niż u dzieci.

Podobny odsetek uczuleń (po 2,93\%) w całej badanej grupie stwierdzono $\mathrm{z}$ dwuchromianem potasu i substancjami zapachowymi. Wcześniej chrom częściej uczulał chorych płci męskiej. Z naszych badań wynika, że u dzieci alergia na ten związek równie często dotyczyła dziewcząt i chłopców. Fakt ten może mieć związek z obecnością tego alergenu w przedmiotach skórzanych. Odsetek dodatnich wyników z dwuchromianem potasu był niższy niż w innych ośrodkach $(5,1-7,3 \%)$ i niższy niż u dorosłych z ośrodka białostockiego $(6,8-8,7 \%)[5,15,16,22]$.

Substancje zapachowe są wykorzystywane na szeroką skalę jako aromaty w przemyśle kosmetycznym. Produkty pielęgnacyjne stosowane w wieku wczesnodziecięcym, jak również kremy i perfumy używane przez młodzież stanowią częste źródło alergii kontaktowej. W całej badanej grupie odsetek uczuleń na substancje zapachowe wyniósł 2,9\% i był trzykrotnie niższy niż u dorosłych (8,3\%), co wskazuje na systematyczny wzrost liczby uczulonych na tę grupę związków z wiekiem [22]. Alergia na substancje zapachowe trzykrotnie częściej występowała u dziewcząt niż u chłopców.

Innym częstym alergenem u badanych pacjentów był balsam peruwiański. Surowiec ten otrzymuje się z drzewa Myroxylon balsamum, charakteryzuje się on przyjemnym zapachem, przypominającym wanilię i cynamon. Ma również właściwości stabilizujące i antyseptyczne. Z tego względu stanowi częsty składnik kosmetyków, perfum oraz produktów spożywczych. W całej grupie alergia ta równie często dotyczyła dziewcząt i chłopców.

Neomycyna zastosowana miejscowo może wywoływać zmiany o charakterze wyprysku kontaktowego. Częstość uczulenia na neomycynę wynosi 4,3-7,1\% [10, 15, 23]. W przedstawionych badaniach wyniosła ona 1,5\% i była większa u dziewcząt. Częstość uczuleń na ten antybiotyk była trzykrotnie mniejsza niż u osób dorosłych. Może to wynikać z jego stosowania zwłaszcza u osób dorosłych w leczeniu owrzodzeń żylnych podudzi. Należy również 
Comparison of the results of patch tests in groups of children and adolescents with AD and without AD showed that the percentage of allergies to nickel in people with AD (9.8\%) was more than twice as low as in patients without AD. Data from other centers indicate that positive results to nickel were observed in $4.9-25 \%$ of patients with AD [13, 16]. Among the subjects with AD, allergy to cobalt was two times more frequent than to nickel (18\% vs. $9.8 \%)$; in the group without AD these proportions were reversed (11.3\% vs. $23.1 \%)$. Silny et al. observed a slightly higher number of cobalt allergies (24\%) in children with $\mathrm{AD}$. In patients without $\mathrm{AD}$, allergy to nickel and cobalt affected girls much more frequently. In younger boys with AD there were no cases of allergy to these metals, whereas among older boys with AD, allergy to nickel and cobalt was significantly more frequent than in a similar group of patients without AD.

The vast majority of cases of sensitization to PPD included patients without $\mathrm{AD}$, while the percentage of positive results with potassium dichromate was almost 6 times higher in patients with AD compared to other patients. A significantly higher frequency of allergies to aromatic substances and balsam of Peru was observed in patients with AD, which may be associated with the use of fragranced skin care products instead of emollients, which are usually without aromatic substances. In the group of people with AD no cases of allergy to neomycin were observed. In studies of Czarnobilska et al., allergy to this drug was observed in $4.9 \%$ of cases [28].

In female patients who were allergic to nickel, cobalt, chromium and aromatic substances, lesions usually occurred on the hands or had a scattered pattern. Similar distribution of skin of lesions was observed in people with AD, who were allergic to cobalt and chromium. In the case of allergy to nickel and aromatic substances, only scattered changes were observed. In both groups of boys who were allergic to these metals, PPD and aromatic substances, changes occurred almost exclusively on the hands. Different location of eczema among girls and boys who were allergic to the same allergen indicates different sources of allergies. In girls it might be cosmetics and jewelry, while in boys it might be skin contact with these allergens while learning a profession or engaging in hobbies. Compared to the results of other centers, allergy to propolis, lanoline and contact allergy were rarely observed among our children ( $0.7 \%$ of cases). In the studies of Czarnobilska et al., allergy to propolis was observed in $16.5 \%$ of children aged 7 and $5.4 \%$ of adolescents aged 16 [28]. In the group of Swedish children, allergy to sheep's wool derivatives occurred in up to $11 \%$ of children, exceeding the percentage of nickel allergy [16]. pamiętać, że neomycyna jako jeden ze składników gotowego leku jest szeroko stosowana szczególnie u dzieci w różnego rodzaju schorzeniach o podłożu alergicznym, bakteryjnym i grzybiczym.

Porównanie wyników prób płatkowych u dzieci i młodzieży z AZS i bez AZS wykazało ponad dwukrotnie niższy odsetek uczuleń na nikiel u osób z AZS (9,8\%) niż u osób bez AZS. Dane z innych ośrodków wskazują, że dodatnie wyniki prób na nikiel stwierdza się u 4,9-25\% chorych na AZS [13, 16]. Wśród badanych z AZS uczulenie na kobalt było dwukrotnie częstsze niż na nikiel (18\% vs 9,8\%), u osób bez AZS proporcje te były odwrotne (11,3\% vs 23,1\%). Nieco wyższe wartości uczuleń na kobalt (24\%) u dzieci z AZS wykazali Silny i wsp. U pacjentów bez AZS alergia na nikiel i kobalt dotyczyła zdecydowanie częściej dziewcząt. U młodszych chłopców z AZS nie stwierdzono przypadków alergii na te metale, natomiast u starszych chłopców z AZS alergia na nikiel i kobalt występowała istotnie częściej niż w podobnej grupie pacjentów bez AZS.

Większość przypadków uczuleń na PPD dotyczyła pacjentów bez AZS, natomiast odsetek dodatnich wyników z dwuchromianem potasu był prawie sześciokrotnie wyższy u pacjentów z AZS w porównaniu z pozostałymi badanymi. Znacznie większą częstość uczuleń na substancje zapachowe i balsam peruwiański obserwowano u chorych na AZS, co może być związane z używaniem perfumowanych preparatów pielęgnacyjnych zamiast emolientów, na ogół pozbawionych substancji zapachowych. U osób z AZS nie stwierdzono żadnego przypadku uczuleń na neomycynę. W badaniach Czarnobilskiej i wsp. alergię na ten lek wykazano u 4,9\% dzieci [28].

U pacjentek uczulonych na nikiel, kobalt, chrom, PPD i substancje zapachowe zmiany najczęściej występowały w obrębie rąk lub miały charakter rozsiany. U osób z AZS uczulonych na kobalt i chrom stwierdzono podobny charakter zmian. W przypadku uczulenia na nikiel, PPD i substancje zapachowe były to wyłącznie zmiany rozsiane. W obu grupach chłopców uczulonych na te metale oraz PPD i substancje zapachowe zmiany występowały prawie wyłącznie na rękach. Różna lokalizacja zmian wypryskowych u dziewcząt i chłopców uczulonych na te same alergeny wskazuje na różne źródła uczuleń. U dziewcząt mogą to być kosmetyki i biżuteria, u chłopców kontakt skóry rąk z tymi alergenami podczas nauki zawodu lub uprawiania hobby. W porównaniu z wynikami badań innych ośrodków w naszym badaniu u dzieci rzadko stwierdzano alergię kontaktową na propolis i lanolinę (0,7\% przypadków). W badaniach Czarnobilskiej i wsp. uczulenie na propolis stwierdzono aż u 16,5\% dzieci w wieku 7 lat i u 5,4\% młodzieży w wieku 16 lat [28]. Wśród szwedzkich dzieci częstość uczulenia na pochodne wełny owczej wynosiła aż $11 \%$, przewyższając odsetek uczulenia na nikiel [16]. 


\section{CONCLUSIONS}

In the past it was believed that contact dermatitis is a rare skin disorder among children. Current research results show, however, that allergic dermatitis is more frequently observed among children and adolescents, including patients with AD. This fact suggests that it is necessary to perform epidermal tests both in children with contact dermatitis and those with AD. With the exception of nickel and cobalt, allergy to many allergens occurs in children and adolescents significantly less frequently than in adults. A worrying phenomenon is the very high percentage of allergies to nickel and cobalt among children and adolescents, especially girls with contact dermatitis and teenage boys with $\mathrm{AD}$. The research results and literature data indicate the existence of significant differences in the frequency of sensitization to particular allergens, depending on the center, as well as the age, sex and co-occurrence of $\mathrm{AD}$.

\section{CONFLICT OF INTEREST}

The authors declare no conflict of interest.

\section{WNIOSKI}

W przeszłości uważano, że wyprysk kontaktowy jest rzadką dermatozą wieku dziecięcego. Obecne wyniki badań wskazują jednak, że alergiczne zapalenie skóry coraz częściej obserwuje się u dzieci i młodzieży, również u pacjentów z AZS. Z tego powodu należy koniecznie wykonywać testy naskórkowe zarówno u dzieci z wypryskiem kontaktowym, jak i z AZS. Z wyjątkiem niklu i kobaltu alergia na wiele alergenów występuje u dzieci i młodzieży istotnie rzadziej niż u dorosłych. Niepokojącym zjawiskiem jest bardzo wysoki odsetek uczulonych na nikiel i kobalt wśród dzieci i młodzieży, zwłaszcza dziewcząt z wypryskiem kontaktowym oraz nastoletnich chłopców z AZS. Uzyskane wyniki badań i dane z piśmiennictwa wskazują na występowanie znacznych różnic w zakresie częstości uczulenia na poszczególne alergeny w zależności od ośrodka, a także wieku, płci i współwystępowania AZS.

\section{KONFLIKT INTERESÓW}

Autorzy deklarują brak konfliktu interesów.

\section{References \\ Piśmiennictwo}

1. Śpiewak R.: Allergic contact dermatitis in children. Nowa Medycyna 2001, 8, $23-26$.

2. Bartoszak L., Czarnecka-Operacz M.: Contact allergy in children with atopic dermatitis. Post Dermatol Alergol 2007, 24, 120-126.

3. Bruckner A.L., Weston W.L., Morelli J.G.: Does sensitization to contact allergens begin in infancy? Pediatrics 2000, 105, e3.

4. Czarnobilska E., Obtułowicz K., Dyga W., Wsołek-Wnęk K., Śpiewak R.: Contact hypersensitivity and allergic contact dermatitis among school children and teenagers with eczema. Contact Dermatitis 2009, 60, 264-269.

5. Śpiewak R.: Allergic eczema in children. Alergologia.biz.pl 2010, 1, 1-8.

6. Śpiewak R.: Patch testing for contact allergy and allergic contact dermatitis. Open Allergy J 2008, 1, 42-51.

7. Śpiewak R.: Contact dermatitis. Post Dermatol Alergol 2009, 26, 375-377.

8. Śpiewak R.: Patch tests. Alergologia.biz.pl 2009, 1, 1-4.

9. Smith V.M., Clark S.M., Wilkinson M.: Allergic contact dermatitis in children: trends in allergens, 10 years on a retrospective study of 500 children tested between 2005 and 2014 in one UK centre. Contact Dermatitis 2016, 74, 37-43.

10. Rodrigues D.F., Goulart E.M.: Patch test results in children and adolescents. Study from the Santa Casa de Belo Horizonte Dermatology Clinic, Brazil, from 2003 to 2010. An Bras Dermatol 2015, 90, 671-683.

11. Lachapelle J.M., Maibach H.I.: Patch testing, prick testing. Springer, Berlin 2003.

12. Hanifin J.M., Rajka G.: Diagnostics features of atopic dermatitis. Acta Derm Venereol 1980, 92, 44-47.

13. Silny W., Bartoszak L., Jenerowicz D., Żukiewicz-Sobczak W., Goździewska M.: Prevalence of contact allergy in children suffering from atopic dermatitis, seborrhoeic dermatitis and in healthy controls. Ann Agric Environ Med 2013, $20,55-60$.

14. Seidenari S., Giusti F., Pepe P., Mantovani L.: Contact sensitization in 1094 children undergoing patch testing over a 7-year period. Pediatr Dermatol 2005, 22, 1-5.13.

15. Schena D., Papagrigoraki A., Tessari G., Peroni A., Sabbadini C., Girolomoni G.: Allergic contact dermatitis in children with and without atopic dermatitis. Dermatitis 2012, 23, 275-280.

16. Isaksson M., Olhardt S., Rådehed J., Svensson Å.: Children with atopic dermatitis should always be patch-tested if they have hand or foot dermatitis. Acta Derm Venereol 2015, 95, 583-586.

17. Akan A., Toyran M., Vezir E., Azkur D., Kaya A., Erkoçoğlu M., et al.: The patterns and clinical relevance of contact allergen sensitization in a pediatric population with atopic dermatitis. Turk J Med Sci 2015, 45, 1207-1213.

18. European Parliament and Council Directive 94/27/EC of 30 June 1994 amending for the $12^{\text {th }}$ time Directive 76/769/EEC on the approximation of the laws, regulations and administrative provisions of the Member States relating to restrictions on the marketing and use of certain dangerous substances and preparations. Official Journal L 1994, 188, 1-2.

19. Jacob S.E., Goldenberg A., Pelletier J.L., Fonacier L.S., Usatine R., Silverberg N.: Nickel allergy and our children's health: a review of indexed cases and a view of future prevention. Pediatr Dermatol 2015, 32, 779-785.

20. Tuchman M., Silverberg J.I., Jacob S.E., Silverberg N.: Nickel contact dermatitis in children. Clin Dermatol 2015, 33, 320-326.

21. Belloni Fortina A., Cooper S.M., Śpiewak R., Fontana E., Schnuch A., Uter W.: Patch test results in children and adolescents across Europe. Analysis of the ESSCA Network 2002-2010. Pediatr Allergy Immunol 2015, 26, 446-455. 
22. Reduta T., Bacharewicz J., Pawłoś A.: Patch test results in patients with allergic contact dermatitis in the Podlasie region. Postep Dermatol Alergol 2013, 30, 350-357.

23. Zug K.A., Pham A.K., Belsito D.V., DeKoven J.G., DeLeo V.A., Fowler J.F. Jr., et al.: Patch testing in children from 2005 to 2012: results from the North American Contact Dermatitis Group. Dermatitis 2014, 25, 345-355.

24. Uter W., Rämsch C., Aberer W., Ayala F., Balato A., Beliauskiene A., et al.: The European baseline series in 10 European Countries, 2005/2006: results of the European Surveillance System on Contact Allergies (ESSCA). Contact Dermatitis 2009, 61,31-38.

25. Rudzki E., Rebandel P.: Three cases of hypersensitivity to p-phenylenediamine (PPD). Alergia Astma Immunologia 2007, 12, 221-224.

26. Chwała C., Buczyłko K., Wagner A.: Contact hypersensitivity to p-phenylenodiamine complicated by allergy to topical steroid treatment in a child with pollinosis - case report. Alergia Astma Immunologia 2011, 16, 105-107.

27. Hogeling M., Pratt M.: Allergic contact dermatitis in children: the Ottawa hospital patch-testing clinic experience, 1996 to 2006. Dermatitis 2008, 19, 86-89.

28. Czarnobilska E., Obtulowicz K., Dyga W., Śpiewak R.: The most important contact sensitizers in Polish children and adolescents with atopy and chronic recurrent eczema as detected with the extended European Baseline Series. Pediatr Allergy Immunol 2011, 22, 252-256.

Received: 18.08 .2016

Accepted: 11.04 .2017

Otrzymano: 18.08.2016 r.

Zaakceptowano: 11.04 .2017 r.

\section{How to cite this article}

Bacharewicz-Szczerbicka J., Reduta T., Pawłoś A., Flisiak I.: Patch test results in children and adolescents suffering from allergic contact dermatitis - comparison of patients with and without atopic dermatitis. Dermatol Rev/Przegl Dermatol 2017, $104,77-91$. DOI: https://doi.org/10.5114/dr.2017.67381 